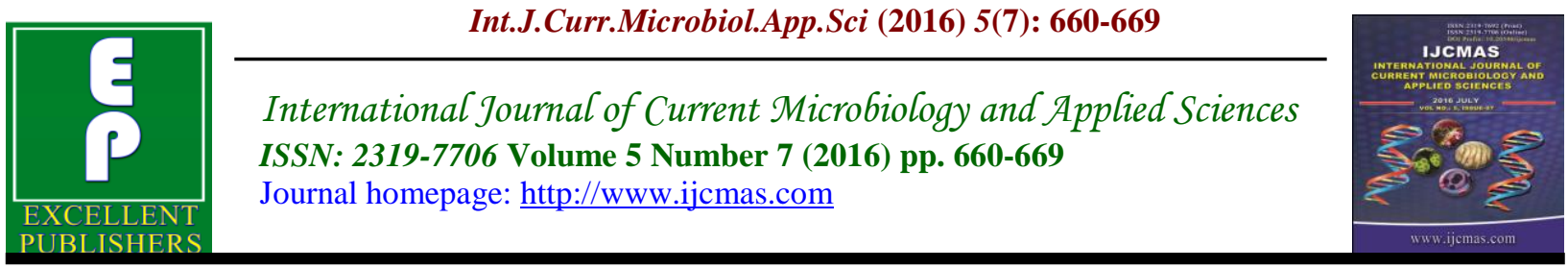

Original Research Article

http://dx.doi.org/10.20546/ijcmas.2016.507.075

\title{
Occult and Chronic Hepatitis B Infection: Relation of Viral Load to Serum Level of 25 Hydroxy Vitamin D
}

\author{
Mervat Mashaly ${ }^{1 *}$, Eman EL Sayed ${ }^{1}$, Gehaan A. Shaker ${ }^{2}$, Rokiah Anwar $^{3}$, \\ Neven Farouk Abbas ${ }^{3}$, Sahar Zakaria ${ }^{4}$ and Enaase A.M.E. Barakat ${ }^{3}$ \\ ${ }^{1}$ Clinical Pathology Department, Faculty of Medicine, Mansoura University-Egypt \\ ${ }^{2}$ Physiology department, Faculty of Medicine, Mansoura University-Egypt \\ ${ }^{3}$ Internal Medicine Department, Faculty of Medicine, Mansoura University-Egypt \\ ${ }^{4}$ Tropical Medicine Department, Faculty of Medicine, Mansoura University-Egypt \\ *Corresponding author
}

Keywords

Occult hepatitis B virus infection, 25 hydroxy vitamin

D, Chronic hepatitis

B infection,

Hepatitis B virus

DNA,

Real time PCR.

Article Info

Accepted:

22 June 2016

Available Online:

10 July 2016
Recent evidence from various lines of research suggested that low levels of vitamin $\mathrm{D}$ are associated with high levels of hepatitis B virus (HBV) replication in chronic hepatitis $\mathrm{B}(\mathrm{CHB})$ infection. However, the relationship between vitamin D and occult hepatitis B infection (OBI) remains unclear. To investigate the pattern of 25 hydroxy vitamin D levels in patients with OBI, we compared serum level of vitamin D among 52 patients with CHB infection, 16 patients with OBI and 34 age $\&$ sex matched healthy control. Hepatitis B envelope $(\mathrm{HBe})$ antigen was assayed among CHB patients. Also, we quantified HBV DNA viral load among both CHB and OBI groups by using Real time PCR. We found that serum level of vitamin D was significantly higher in patients with OBI than those with $\mathrm{CHB}$ infection but it was insignificantly differ from healthy control. Patients with $\mathrm{HBe} \mathrm{Ag}$ negative had a significantly higher serum level of vitamin $\mathrm{D}$ than those with $\mathrm{HBe} \mathrm{Ag}$ positive. Serum level of vitamin D was inversely correlated with HBV DNA viral load. It could be concluded that adequate levels of vitamin D may be one of the factors limiting the replication of HBV and decreasing viral load in patients with OBI.

\section{Introduction}

Hepatitis B vaccine is available since 1982, but hepatitis B virus (HBV) infection is still a major public health problem worldwide because of its significant mortality and morbidity. Worldwide, almost 240 million individual are chronically infected with HBV (WHO, 2015). It is the reason for around half of the world's cases of hepatocellular carcinoma (HCC) and around
$30 \%$ of all cases of liver cirrhosis, causing more than 780,000 deaths for every year (ElSeraq, 2011) and (Gish and Locarnini, 2007). In Egypt, hepatitis B surface antigen (HBsAg) prevalence is of moderate endemicity (2-8\%). Furthermore, almost 2-3 million Egyptians are chronic carriers of HBV (Attia, 1998). 
A wide range of clinical features, extending from an inactive carrier state to, cirrhosis, hepatocellular carcinoma or fulminate hepatitis, can induced by $\mathrm{HBV}$ infection (Torbenson and Thomas, 2002).

Occult HBV infection (OBI) is defined as the existence of HBV DNA in the serum, cells of the lymphatic (immune) system, and/or hepatic tissue in the absence of serum HBsAg (Bréchot et al., 2001). The pathogenesis of OBI could be explained by many possible mechanisms and the condition is most likely multifactorial. Factors related to both host and virus appear to have parts in suppression of viral replication and holding the infection under control (Said, 2011) and (Torbenson and Thomas, 2002). In addition, the extremely low or undetectable levels of serum HBV DNA in OBI could be due to strong suppression of viral replication and gene expression by antiviral cytotoxic $\mathrm{T}$ cells (Bes et al., 2012).

Vitamin D is a fat soluble vitamin which is essential for different physiological and biological functions in the human body. The biologically active form of vitamin D, Calcitriol (1, 25 hydroxy vitamin D), acts like a hormone and functions mainly to maintain calcium and phosphorus homeostasis in the body (National Institute of Health, 2014), (National Cancer Institute, 2014).

The ability of this biologically active form of vitamin $\mathrm{D}$ to modulates the adaptative immune system by direct impacts on proliferation of $\mathrm{T}$ and $\mathrm{B}$ cells and maturation of dendritic cells (DCs) has created research interest (Deluca and Cantorna, 2001).

Studies exploring the link between HBV infection and vitamin $\mathrm{D}$ level are limited. However, A study on spontaneous seroclearance of HBsAg found that there is a positive correlation between HBsAg seroclearance and vitamin D levels (Mahamid et al., 2013). Another study demonstrated a significant association between higher levels of HBV replication and low levels of serum vitamin D in CHB patients (Farnik et al., 2013). Given this information, we hypothesized that vitamin D level could be one of the factors responsible for the very low serum levels of HBV DNA in OBI. So, the aim of our study was to investigate the pattern of vitamin $\mathrm{D}$ levels in patients with occult HBV infection compared with chronic HBV infection and healthy individuals.

\section{Patients and methods}

Patients for this study were selected from those attending for follow up in the outpatient clinic of Specialized Medical Hospital - Mansoura University. Fifty-two patients diagnosed with chronic hepatitis B infection ( $\mathrm{HBs} \mathrm{Ag}$ positive, anti-HBs $\mathrm{Ab}$ negative for at least six months) and sixteen patients diagnosed with occult $\mathrm{HBV}$ (HBs Ag negative but HBV DNA was detected in their blood by qualitative PCR) were included in our study. In addition, thirty-four healthy subjects without a history, or serological or molecular proof of chronic $\mathrm{HBV}$ infection (HBs Ag negative and no HBV DNA was detected in their blood by qualitative PCR) were served as a control group.

Subjects with metabolic bone diseases, chronic renal failure, heart failure, thyroid, parathyroid diseases, Cushing's syndrome, intestinal mal absorption, receiving calcium or vitamin D substitution therapy, hepatitis C, hepatitis, HIV infection, systemic bacterial or fungal infection were excluded from the present study. All participants signed consent and an ethical approval was 
granted for this study from the Local Ethical Committee of Faculty of MedicineMansoura University (MFM- Institutional Research Board) and the code number is $\mathrm{R} / 16.05 .91$.

\section{Sampling}

$3 \mathrm{~mL}$ venous blood sample was withdrawn and distributed into two tubes;

- One $\mathrm{mL}$ into EDTA vacutainer tube for DNA extraction \& analysis and stored at -70 $\mathrm{C}^{\circ}$ till analysis

- Two mL into plain tube (for $\mathrm{HBe} \mathrm{Ag}$ and vitamin D assay) allowed to clot for 15 minutes and centrifuged at $7000 \mathrm{rpm}$ for 5 minutes and the serum was collected and stored at $-70 \mathrm{C}^{\circ}$ till analysis.

\section{Methods of assays}

HBe antigen was assayed for $\mathrm{CHB}$ patients $(n=52)$ by an enzyme-linked immunosorbent assay (ELISA) using Diasorin kit (Diasorin, Italy) according to manufacturer's instructions.

$25(\mathrm{OH})$ vitamin $\mathrm{D}$ was quantified for all subjects included in this study; CHB $(\mathrm{n}=52)$, OBI $(n=16) \&$ control $(n=34)$ by an enzymelinked immunosorbent assay (ELISA) using the DRG kit (DRG International Inc, USA) according to manufacturer's instructions. Serum vitamin $\mathrm{D}$ concentration was categorized as deficient if it was less than 10 $\mathrm{ng} / \mathrm{mL}$, insufficient if it was $10-29 \mathrm{ng} / \mathrm{mL}$ and adequate when it was $30-100 \mathrm{ng} / \mathrm{ml}$ (Holick, 2002).

Molecular analysis for HBV: Detection of OBI was done among $100 \mathrm{HBs}$ Ag negative blood donners by conventional PCR then quantification of HBV DNA viral load was performed for both OBI $(\mathrm{n}=16)$ and $\mathrm{CHB}$ $(\mathrm{n}=52)$ groups.
HBV DNA extraction from whole blood was done using QIAamp DNA blood Min Kit (Qiagen, USA) following manufacture's instructions.

Amplification of HBV DNA was performed using a 9700 thermocycler (PE, Applied Biosystems, USA) according to the method described by Naito et al. (2000). We used the primer pair; P1 (5'-TCA CCA TAT TCT TGG GAA CAA GA-3'(Nucleotide 2823- 2845, universal sense) and S1-2 (5'CGA ACC ACT GAA CAA ATG GC-3'. (Nucleotide 685-704, universal antisense) to target Pre S1 through S genes within the HBV genome. The PCR was performed in a $50 \mu 1$ reaction mixture volume containing 25 ul of master mix (dNTPs, Taq DNA polymerase and PCR buffer), 3 ul of primer P, 3 ul of primer S1-2, 9 ul of distilled water and 10 ul of DNA extract. The cycling conditions comprised of preheating at $95 \mathrm{C}^{\circ}$ for $10 \mathrm{~min}$ followed by 40 cycles of amplification at; $94 \mathrm{C}^{\circ}$ for $20 \mathrm{sec}$ (Denaturation), $55 \mathrm{C}^{\circ}$ for $20 \mathrm{sec}$ (Annealing) and $72 \mathrm{C}^{\circ}$ for $1 \mathrm{~min}$ (extension) then finally one cycle at $72 \mathrm{C}^{\circ}$ for $5 \mathrm{~min}$ (Post extension). Positive and negative controls were run alongside the clinical samples. The amplified DNA product was analyzed by running $10 \mu \mathrm{l}$ of amplicon on a $2 \%$ agarose gel after addition of $4 \mu \mathrm{l}$ loading dye. To estimate the molecular weights of DNA fragments in the gel, $100 \mathrm{bp}$ DNA ladder was also run in agrose gel. Examination of agarose gel was done utilizing UV transilluminator for detection of particular band. The presence of a $1063 \mathrm{bp}$ fragment indicated positive result for OBI.

Real time PCR: was performed to quantify HBV DNA viral load in CHB $(n=52)$ and OBI $(n=16)$ groups. Quantification was done by a Taqman probe based technique using Artus QS-RGQ kit (Qiagen, Hilden, Germany) on a Step One real time PCR (Applied Biosystems, USA) following 
manufacture's instructions. Briefly, amplification was carried out in a $50 \mu \mathrm{l}$ reaction mixture containing: $30 \mu \mathrm{l}$ of Artus HBV TM PCR master mix (ready to use) and $20 \mu \mathrm{l}$ of extracted DNA. The reaction was performed under the following thermal profile: AmpliTaq activation at $95^{\circ} \mathrm{C}$ for 10 min, followed by 45 cycles for DNA amplification; each cycle consisted of denaturation at $95^{\circ} \mathrm{C}$ for 15 secs, annealing at $55^{\circ} \mathrm{C}$ for $30 \mathrm{secs}$ and extension at $72^{\circ} \mathrm{C}$ for 15 secs. All the five standard provided by the Artus QS-RGQ kit were amplified and detected as previously treated samples using Step One real time PCR. Standard curves were generated using the in-built software and used to relate $\mathrm{Ct}$ values to the initial copy number of the unknown samples.

\section{Statistical analysis}

Data were analyzed using SPSS statistical package programme (version 16, SPSS, Chicago, IL). Normal distribution of variables was tested with the KolmogorovSmirnov test. The results were expressed as percentages for categorical variables, mean \pm SD for normally distributed variables and as median (range) in non-normal distributed variables.

For comparison between two groups, Student-t test was used for normally distributed variables and the Mann-Whitney U test was used for non normally distributed variables. Chi-Square test were used for analysis of categorical variables. Pearson correlation coefficient test was used to test a positive or negative relationship between two quantitative variables. For all statistical tests, $\mathrm{p}$ value of $\leq 0.05$ was considered statistically significant.

\section{Results and Discussion}

This study was carried out on 52 patients with chronic HBV infection (with $\mathrm{HBs}$ Ag positive, anti-HBs $\mathrm{Ab}$ negative for more than 6 months) , 16 patients with occult HBV (HBs Ag negative but with HBV DNA detected in their blood by qualitative PCR) and 34 healthy subjects (with $\mathrm{HBs} \mathrm{Ag}$ negative and no HBV DNA was detected in their blood by qualitative PCR) served as a control group. All patients were selected form Specialized Medical Hospital Mansoura University. Out of 52 patients with chronic HBV infection, 46 (88.5\%) cases were $\mathrm{HBe} \mathrm{Ag}$ negative $\mathrm{e}$ and 6 (11.5\%) cases were HBe Ag positive.

The average age of $\mathrm{CHB}$, OBI patients and control groups were, $43.0 \pm 3.2$ years, $41.9 \pm$ 2.4 years \& $41.71 \pm 2.5$ respectively and there was no statistically significant difference between the groups $(\mathrm{p}=0.099)$. $65.4 \%, 62.5 \% \& 64.7 \%$ of $\mathrm{CHB}, \mathrm{OBI}$ and control groups were male respectively. Gender were similar in patients and control groups $(\mathrm{p}=0.978)$.

Our study revealed that there was no statistically significant difference in serum level of 25 vitamin $D$ between patients with occult hepatitis B and healthy control (22.4 \pm 10.3 vs $21.1 \pm 8.7 \mathrm{ng} / \mathrm{ml}, \mathrm{p}=0.6$ ), whereas serum level of 25 vitamin $D$ in patients with chronic hepatitis B was below that of healthy control and the difference between them was statistically significant $(11.4 \pm 6.7$ $\mathrm{ng} / \mathrm{ml}$ vs $21.1 \pm 8.7 \mathrm{ng} / \mathrm{ml}$ ). Moreover, serum level of vitamin D was significantly higher in patients with occult HBV infection than those with chronic HBV infection (22.4 \pm 10.3 vs $11.4 \pm 6.7 \mathrm{ng} / \mathrm{ml}, \mathrm{p}=0.001)$. Furthermore, we detected that patients with HBe Ag negative had a significantly higher level of $25(\mathrm{OH}) \mathrm{D}$ serum level than those with $\mathrm{HBe} \mathrm{Ag}$ positive $(12.2 \pm 6.5$ vs $5.3 \pm$ $4.7 \mathrm{ng} / \mathrm{ml}, \mathrm{p}=0.016)$, table $(1)$.

As shown in figure (1), $25(\mathrm{OH})$ vitamin D deficiency $(<10 \mathrm{ng} / \mathrm{ml})$ was detected in 
$12.50 \%, 40.40 \%, 83.30 \%, 34.80 \%$ and 5.9 $\%$ of occult HBV, chronic HBV, $\mathrm{HBe}$ Ag positive, $\mathrm{HBe} \mathrm{Ag}$ negative and control groups respectively. This percentage of patients with vitamin D deficiency was statistically significantly less in patients with occult hepatitis $\mathrm{B}$ than patients with chronic hepatitis B $(12.50 \%$ vs $40.40 \%$, p= 0.04$)$, whereas the percentage of patients with vitamin $\mathrm{D}$ deficiency was statistically insignificant higher in patients with occult hepatitis B when compared to healthy control $(12.50 \%$ vs $5.9 \%, \mathrm{p}=0.42)$. In addition, presence of $\mathrm{HBe} \mathrm{Ag}$ was significantly associated with severe deficiency of vitamin $\mathrm{D}(\mathrm{P}=0.02)$.

In addition, detection of HBV-DNA viral load by real time PCR in both chronic HBV $(\mathrm{n}=52)$ and occult HBV $(\mathrm{n}=16)$ groups revealed that $27(39.7 \%)$ cases had undetectable levels of HBV DNA $(<12$ $\mathrm{IU} / \mathrm{mL})$. Of these 27 cases, $24(35.3 \%)$ cases were $\mathrm{HBs} \mathrm{Ag}$ positive but they were $\mathrm{HBe} \mathrm{Ag}$ negative (inactive carrier) and the remaining 3 (4.4\%) cases were occult HBV. Median level (range) of HBV-DNA load in occult $\mathrm{HBV}$ was $45 \mathrm{IU} / \mathrm{ml}(34-110)$ which was statistically significant lower than those in chronic $\mathrm{HBV} 805.50 \mathrm{IU} / \mathrm{ml}$ (75 216184). Moreover, HBe Ag positive patients showed significantly higher median level (range) of HBV-DNA load in comparison to $\mathrm{HBe} \mathrm{Ag}$ negative patients [148359.5 IU/ml (509 - 216184) vs 326 IU/ml (75 -19237) ] table (1).

Pearson correlation analysis among both chronic \& occult HBV patients and among occult HBV patients only revealed a strong significant, inverse correlation between serum level of $\log 10 \mathrm{HBV}$ DNA (IU/ml) viral load and serum level of $25(\mathrm{OH})$ vitamin $\mathrm{D}(\mathrm{ng} / \mathrm{ml})(\mathrm{r}=0.77, \mathrm{p}=0.000) \&(\mathrm{r}=$ $-0.82, p=0.001)$ respectively figure (2) and figure (3). To ascertain the extent to which serum level of $25(\mathrm{OH})$ vitamin D can predict HBV DNA viral load, we performed simple linear regression analysis. We found that the regression model predicted $59 \%$ of variance $(\mathrm{B}=-0.09, \mathrm{SE}=0.013,95 \% \mathrm{CI}=$ $0.125--0.07, \mathrm{P}=0.000)$ among both chronic $\&$ occult HBV patients and predicted $66 \%$ of variance $(B=-0.117, S E=0.016,95 \% C I=$ - 0.149 - $-0.08, \mathrm{P}=0.000$ ) among occult HBV patients only.

Occult HBV infection is a complex clinical entity reported worldwide. It is defined as the presence of HBV DNA in the liver (with or without detectable HBV DNA in the serum) in $\mathrm{HBs} \mathrm{Ag}$ - negative individuals tested with the currently available serum assays (Raimondo et al., 2008), (Torbenson and Thomas, 2002 ).

Several mechanisms have been suggested for the occurrence of OBI. These extend from integration of viral genome in the host chromosomes, S gene helix mutations (not detected in diagnostic tests), the window phase after acute infection, suppression of the host immunity, HCV co-infection competing with $\mathrm{HBV}$ and utilization of serology kits with low sensitivity and specificity to HBsAg (Akarsu et al., 2011).

Also, many mechanisms related to host immune response, for example; apoptosis, cytolytic and noncytolytic T-cell responses, have been linked to modulation of HBV replication \& synthesis of HBV protein and have been suggested for the pathogenesis of OBI (Samal et al., 2012).

Vitamin D is a vital part of human diet having a conventional role in mineralization of bone (Kitson and Roberts, 2012). Recently, Vitamin D is found as an essential modulator of immunity and plays an emerging role in inflammatory and metabolic liver diseases, including hepatitis C virus infection (Holick, 2011). 
The possible role of vitamin $\mathrm{D}$ in regulating host defense against foreign antigens and pathogens has been ascribed to the discovery that many of immune cells express vitamin $\mathrm{D}$ receptor (VDR) and the immune cells can produce CYP27B1 (1 $\alpha$-hydroxylase) enzyme and can change over $25(\mathrm{OH})$ vitamin $\mathrm{D}$ into $1,25(\mathrm{OH}) 2$ vitamin $\mathrm{D}$ (Rosa et al., 2011). This $1,25(\mathrm{OH}) \mathrm{D} 3$ increases the regulatory $\mathrm{T}$ cells and improves the release of IL-10, and reduces the IL-2 secretion from dendritic cells (Baig, 2015). Additionally, discovery that VDR polymorphism, due to base change in the 352th codon of VDR gene, has a role in hepatitis $\mathrm{B}$ infection being chronic makes us assume that 25(OH)D serum level might be one of the variables responsible for the very low or undetectable serum levels of HBV DNA in OBI (Bellamy et al., 1999).

Table.1 25(OH) vitamin D serum level (ng/dl) and HBV DNA viral load (IU/mL) among different groups

\begin{tabular}{|c|c|c|c|c|c|c|c|c|c|}
\hline & \multicolumn{3}{|l|}{$\begin{array}{l}\text { Chronic HBV } \\
(n=52)\end{array}$} & \multirow{2}{*}{$\begin{array}{l}\text { Occult } \\
\text { HBV } \\
(n=16)\end{array}$} & \multirow[t]{2}{*}{$\begin{array}{l}\text { Control } \\
(n=34)\end{array}$} & \multirow[t]{2}{*}{ P1 } & \multirow[t]{2}{*}{ P2 } & \multirow[t]{2}{*}{ P3 } & \multirow[t]{2}{*}{ P4 } \\
\hline & $\begin{array}{l}\text { HBe Ag +ve } \\
(n=6)\end{array}$ & $\begin{array}{l}\text { HBe Ag-ve } \\
(n=46)\end{array}$ & $\begin{array}{l}\text { Total } \\
(n=52)\end{array}$ & & & & & & \\
\hline $\begin{array}{l}25(\mathrm{OH}) \mathrm{D} \text { level } \\
\text { Mean } \\
+\mathrm{SD}\end{array}$ & $5.3 \pm 4.7$ & $12.2 \pm 6.5$ & $11.4 \pm 6.7$ & $22.4+10.3$ & $21.1 \pm 8.7$ & 0.001 & 0.016 & 0.000 & 0.6 \\
\hline $\begin{array}{l}\text { HBV DNA load } \\
\text { Median } \\
\text { (range) }\end{array}$ & $\begin{array}{l}148359.5 \\
(509-216184)\end{array}$ & $\begin{array}{l}326 \\
(75-19237)\end{array}$ & $\begin{array}{l}805.50 \\
(75-216184)\end{array}$ & $\begin{array}{l}45 \\
(34-110)\end{array}$ & - & 0.000 & 0.001 & & \\
\hline
\end{tabular}

P1: chronic HBV vs Occult HBV, P2: HBe Ag +ve vs $\mathrm{HBe} \mathrm{Ag}-\mathrm{ve}, \mathrm{P} 3$ : chronic HBV vs Control, P4: Occult HBV vs Control

Fig.1 Percentage of patients with vitamin D levels below normal

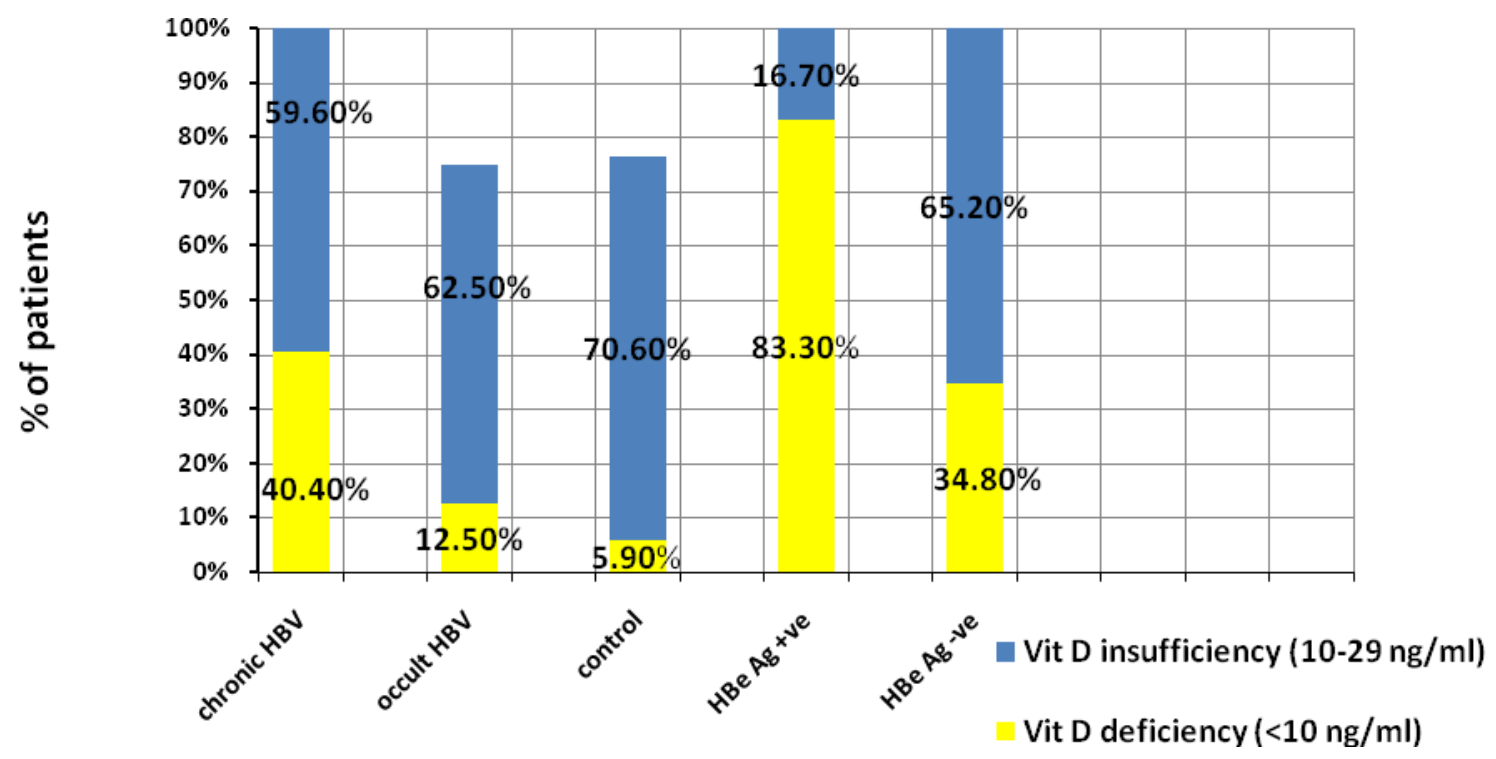


Fig.2 Correlation between $25(\mathrm{OH})$ vitamin D and HBV DNA (Log 10) levels in both chronic and occult HBV patients

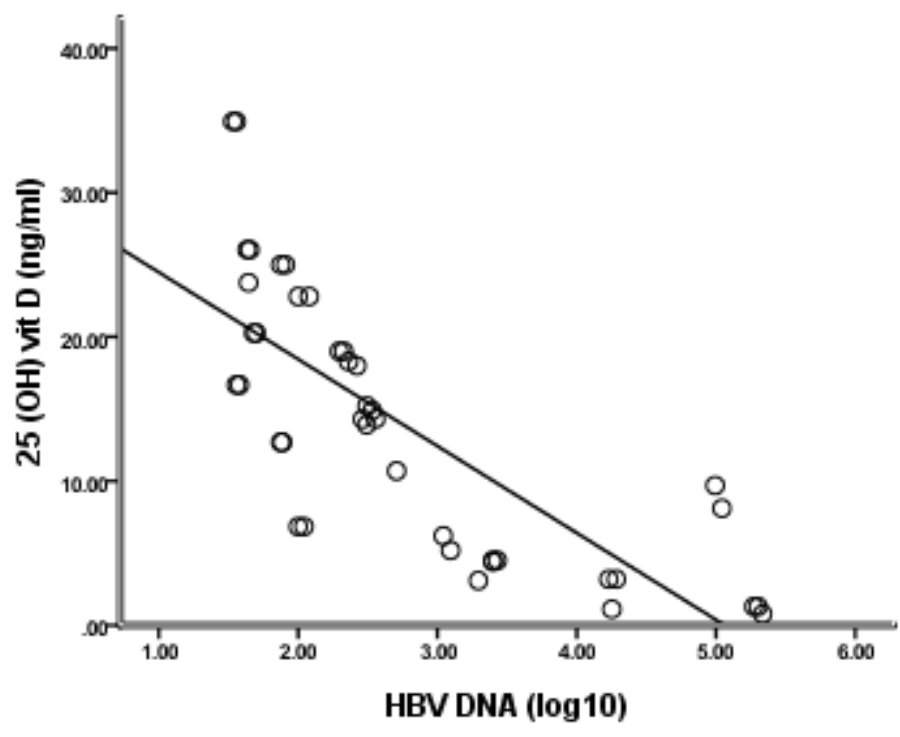

Fig.3 Correlation between $25(\mathrm{OH})$ vitamin D and HBV DNA (Log 10) levels in occult HBV patients

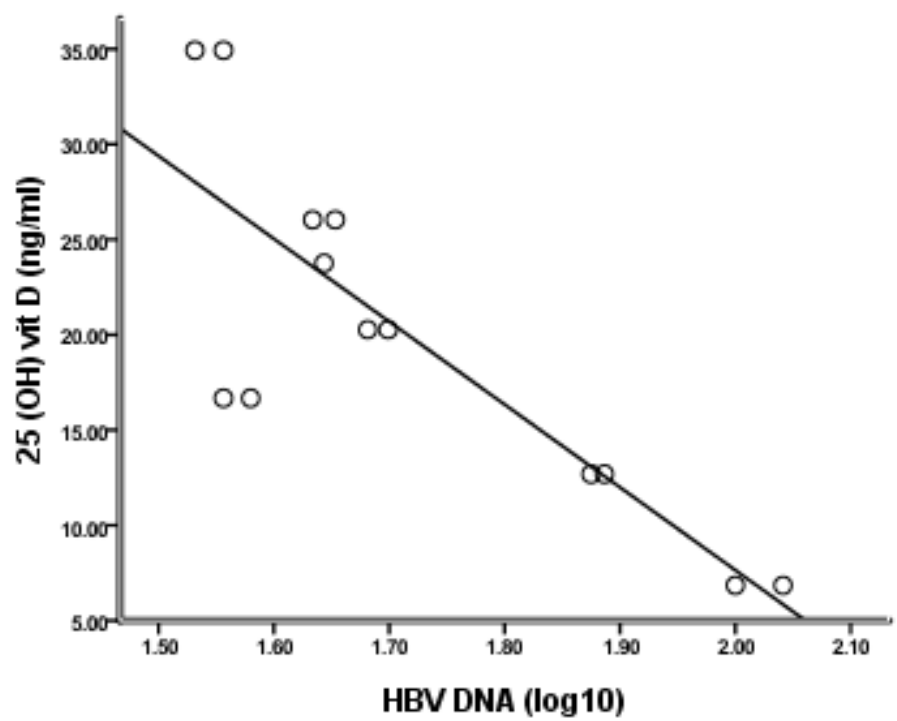

As for the best of our knowledge, this is the first research in aspect of evaluating the relationship between occult $\mathrm{HBV}$ infection and vitamin $\mathrm{D}$ in the literature.

In our study we demonstrated that $25(\mathrm{OH}) \mathrm{D}$ level was significantly higher in patients with occult $\mathrm{HBV}$ infection than those with chronic HBV infection $(22.4 \pm 10.3$ vs 11.4 $\pm 6.7 \mathrm{ng} / \mathrm{ml}, \mathrm{p}=0.001)$ but it was insignificantly differ from healthy control $(22.4 \pm 10.3$ vs21.1 $\pm 8.7 \mathrm{ng} / \mathrm{ml}, \mathrm{p}=0.6)$. Also, we found that $25(\mathrm{OH}) \mathrm{D}$ level was significantly lower in patients with chronic HBV infection than control $(11.4 \pm 6.7 \mathrm{vs}$ $21.1 \pm 8.7)$. This is in agreement with Demir 
et al. (2015) and Candvir Ulu et al. (2015) who found that chronic $\mathrm{HBV}$ patients had significantly lower levels of $25(\mathrm{OH}) \mathrm{D}$ than the control group.

Hepatitis B e antigen had proved to be a distinct marker of HBV replication (Dentico et al., 1980). This is consistent with our findings that $\mathrm{HBe} \mathrm{Ag}$ positive patients had a significant higher median level (range) of HBV-DNA load in comparison to $\mathrm{HBe} \mathrm{Ag}$ negative patients. This is in agreement with Gupta et al., (2012) who found that HBV DNA load is higher in HBe antigen-positive than in $\mathrm{HBe}$ antigen-negative patients.

Moreover, We detected that patients with $\mathrm{HBe} \mathrm{Ag}$ negative had a significantly higher level of $25(\mathrm{OH}) \mathrm{D}$ serum contraction than those with $\mathrm{HBe} \mathrm{Ag}$ positive $(12.2 \pm 6.5$ vs $5.3 \pm 4.7 \mathrm{ng} / \mathrm{ml}, \mathrm{p}=0.016$ ).

Median level (range) of HBV-DNA load in occult HBV was statistically significant lower than those in chronic HBV $45 \mathrm{IU} / \mathrm{ml}$ (34-110) vs $805.50 \mathrm{IU} / \mathrm{ml}$ (75-216184). Thus, OBI seems to be mainly linked to a strong suppression of viral replication (Fuente et al., 2011).

In spite Candevir Ulu and his colleague (2015 ) did not find a correlation between HBV DNA levels \& 25(OH)D levels and they attributed this lack of correlation to low patient number and seasonal change of vitamin $\mathrm{D}$ levels. We detected a significant inverse correlation between serum levels of $\log 10 \mathrm{HBV}$ DNA (IU/ml) viral load and 25(OH)D (ng/ml) among both CHB \&OBI patients as well as among OBI group only.

This is similar to Farnik et al. (2013) who showed that $25(\mathrm{OH})$ D levels were significantly lower in patients with $\mathrm{HBV}$ DNA levels (>2000 IU/ml). Also, Mohamadkhani et al., (2015) showed a significant inverse relationship between vitamin $\mathrm{D}$ levels and $\mathrm{HBV}$ replication in patients with chronic infection. Thus, it could be suggested that adequate levels of vitamin $D$ may be one of the factors limiting HBV replication and reducing viral load in patients with OBI.

1.25 dihydroxy-vitamin $\mathrm{D}$ stimulate secretion of cathelicidin (LL-37) from the neutrophil granules via VDR. Cathelicidin mainly target enveloped virus and disrupt the lipid membrane of their envelope. Furthermore, it prevents viral entry into the host cell (Beard et al., 2011). Recently, Mohamadkhani et al., (2015) demonstrated that suppression of viral replication in patients with $\mathrm{CHB}$ infection may be mediated by vitamin $D$ through increasing the expression of a unique miRNA "miR$378^{\prime \prime}$.

In conclusion, our results demonstrated that vitamin $D$ levels among OBI is insignificantly differ from healthy control and the replication of $\mathrm{HBV}$ is limited in patients with adequate levels of vitamin $\mathrm{D}$. So, it could be suggested that adequate levels of vitamin D may be one of the factors limiting the replication of $\mathrm{HBV}$ and decreasing viral load in patients with OBI.

\section{Acknowledgements}

We would like to thank the patients of the Internal Medicine Department \& to express our sincere gratitude to the laboratory technicians for their valuable efforts.

\section{References}

Akarsu, $\quad$ M., Kantar, F.U., Sayiner, A. 2011. Occult hepatitis B: Evolving challenges and new perspectives. Hepat. Mon., 11: 475476.

Attia, M.A. 1998. Prevalence of hepatitis B and $\mathrm{C}$ in Egypt and Africa. Antivir 
Ther., 3: 1-9.

Baig, S., Mushtaq, S., Ahmed, S., Shahid, M. 2015. The Role of Vitamin D in HBV infection. European $J$. Biotechnol. Biosci., 3(2): 35-41.

Beard, J.A., Bearden, A., Striker, R. 2011. Vitamin D and the anti-viral state. $J$. Clin. Virol., 50: 194-200.

Bellamy, R., Ruwende, C., Corrah, T., McAdam, K.P., Thursz, M., Whittle, H.C., Hill, A.V. 1999. Tuberculosis and chronic hepatitis $B$ virus infection in Africans and variation in the vitamin $\mathrm{D}$ receptor gene. J. Infect. Dis., 179: 721-724.

Bes, M., Vargas V., Pironetal, M. 2012. "T cell responses and viral variability in blood donation candidates with occult hepatitis B infection". J. Hepatol., 56: 765-774.

Bréchot, C., Thiers, V., Kremsdorf, D., Nalpas, B., Pol, S., Paterlini-Bréchot, P. 2001. Persistent hepatitis B virus infection in subjects without hepatitis B surface antigen: clinically signifcant or purely "occult"? Hepatol., 34: 194203.

Candevir Ulu, A., Kuscu, F., Seza, I. A., Komur, S., Kurtaran, B., Nazik, S., Tasova, Y., Salih, Z.H. 2015. Vitamin D Levels and Hepatitis B: Is There Any Relationship? Viral Hepatitis J., 21(2): 44-47

Deluca, H.F., and Cantorna, M.T. 2001. "Vitamin D: its role and uses in immunology". The FASEB J., 15: 2579 - 2585.

Demir, C., Demir, M. 2013. Vitamin D levels in patients with chronic hepatitis $B$ virus infection and naturally immunized individuals. Internal Medicine Inside., 1: 2.

Dentico, P., Buongiorno, R., Angarano, G., Monno, L., Coppola ,S., Laddago, V., Spinelli, A., Pastore, G. 1980. Markers of viral replication $(\mathrm{HBeAg}$ and DNA polymerase activity) in chronic uremia, HBsAg positive, hemodialysis patients. Boll. Soc. Ital. Biol. Sper., 56(21): 2193-9.

El-Seraq, H.B. 2011. Hepatocellular carcinoma. N. Engl. J. Med., 365(12): 1118-1127.

Farnik, H., Bojunga, J., Bergr, A., et al. 2013. Low vitamin D serum concentration is associated with high levels of hepatitis B virus replication in chronically infected patients. Hepatol., 58(4): 1270-1276.

Fuente, D.R.A., Gutierrez, M.L., GarciaSamaniego, J., Fernandez-Rodriguez, C., Lledo, J.L., Castellano, G. 2011. Pathogenesis of occult chronic hepatitis B virus infection. World J. Gastroenterol., 17: 1543-1548.

Gish, R.G., and Locarnini ,S. 2007. Genotyping and genomic sequencing in clinical practice. Clin. Liver Dis., 11(4): 761-795.

Gupta, E., Kumar, A., Choudhary, A., Kumar, M., Sarin, S. K. 2012: Serum hepatitis B surface antigen levels correlate with high serum HBV DNA levels in patients with chronic hepatitis B: A cross-sectional study. Indian J. Med. Microbiol., 30: 150-4.

Holick, M. 2002. Vitamin D: the under appreciated D- lightful hormone that is important for skeletal and cellular health. Curr. Opin. Endocrinol. Diabetes., 9 (1): 87-98.

Holick, M.F. 2011. Vitamin D: Evolutionary, physiological and health perspectives. Curr. Drug Target., 12: 4- 18.

Kitson, M.T., Roberts, S.K. 2012. D-livering the message: the importance of vitamin D status in chronic liver disease. J. Hepatol., 57: 897-909.

Mahamid, M., Nseir, W., AbuElhija, O., et al. 2013. Normal vitamin D levels are associated with spontaneous hepatitis 
B surface antigen seroclearnce. World J. Hepatol., 5(6): 328-331.

Mohamadkhani, A., Bastani, F., Khorrami, S., Ghanbari, R., Eghtesad, S., Sharafkhah, M., Montazeri, G., Poustchi, H .2015. Negative Association of Plasma Levels of Vitamin D and miR-378 With Viral Load in Patients With Chronic Hepatitis B Infection. Hepat. Mon., 15(6): e28315.

Torbenson, M. and homas, D.L. 2002. "OcculthepatitisB,". Lancet Infect. Dis., 2(8): 479-486.

Naito, H., Hayashi, S., Abe, K. 2000. The entire nucleotide sequence of two hepatitis $\mathrm{G}$ virus isolates belonging to a novel genotype: isolation in Myanmar and Vietnam. J. Gen. Virol., 81: 189-194.

National Institute of Health. Vitamin D. http://ods.od.nih.gov/factsheets/Vitami nD-HealthProfessional/. Updated June 24, 2011. Accessed March 31, 2014.
National Cancer Institute. Vitamin D and cancer prevention. http://www.cancer. gov/cancertopics/factsheet/prevention /vitamin-D. Updated October 21, 2013. Accessed March 31, 2014.

Raimondo, G., et al. 2008. Statements from the Taormina expert meeting on occult hepatitis B virus infection. J. Hepatol., 49: 652-657.

Said, Z.N. 2011. An overview of occult hepatitis B virus infection. World $J$. Gastroenterol., 17: 1927-1938.

Samal, J., Kandpal, M., Vivekanandan,P. 2012. Molecular Mechanisms Underlying Occult Hepatitis B Virus Infection. Clin. Microbiol. Rev., $142-$ 163

Rosa, D., Malaguarnera, M., Nicoletti, F., Malaguarnera, L. 2011. Vitamin D3: A helpful immuno-modulator. Immunol., 134: 123-139.

WHO. 2015. Hepatitis B. World Health Organization Fact sheet $\mathrm{N}^{\circ} 204$.

\section{How to cite this article:}

Mervat Mashaly, Eman EL Sayed, Gehaan A. Shaker, Rokiah Anwar, Neven Farouk Abbas, Sahar Zakaria and Enaase A.M.E. Barakat. 2016. Occult and Chronic Hepatitis B Infection: Relation of Viral Load to Serum Level of 25 Hydroxy Vitamin D. Int.J.Curr.Microbiol.App.Sci. 5(7): 660-669. doi: http://dx.doi.org/10.20546/ijcmas.2016.507.075 